Scientific Journal. ISSN 2595-9433

Volume 1, Number 1, Article n. 6, January/March

D.O.I. http://dx.doi.org/10.35418/2526-4117/v1n1a6

Accepted: 12/07/2018 Published: 05/03/2019

\title{
GENETIC VARIABILITY ON NUTRIENT CONTENTS IN Coffea canephora GENOTYPES CULTIVATED AT 850 METERS OF ALTITUDE IN TWO CROP SEASONS
}

\author{
Madlles Queiroz Martins ${ }^{1,3}$, Fábio Luiz Partelli², Adésio Ferreira ${ }^{3}$, Carolina de Oliveira Bernardes ${ }^{3}$, \\ Adelmo Golynski ${ }^{4}$, Henrique Duarte Vieira ${ }^{5}$, Marta Simone Mendonça Freitas ${ }^{5}$, \\ José Cochicho Ramalho ${ }^{6,7}$
}

\begin{abstract}
${ }^{1}$ Programa de Pós-Graduação em Genética e Melhoramento, Centro de Ciências Agrárias e Engenharias, Universidade Federal do Espírito Santo, Alto Universitário, $s / n^{\circ}$ - Guararema, Alegre - ES |CEP 29500-000, Brazil.

${ }^{2}$ Departmento de Ciências Agrárias e Biológicas, Centro Universitário Norte do Espírito Santo, Universidade Federal Espírito Santo, Rodovia Governador Mário Covas, Km 60 - Bairro Litorâneo, São Mateus - ES | CEP 29932-540, Brazil.

${ }^{3}$ Departamento de Agronomia, Centro de Ciências Agrárias e Engenharias, Universidade Federal do Espírito Santo, Alto Universitário, s/ $n^{\circ}$ - Guararema, Alegre - ES | CEP 29500-000, Brasil.

${ }^{4}$ Instituto Federal Goiano, Campus de Morrinhos, Rodovia BR-153, Km 633, Zona Rural. Caixa Postal 92, CEP 75650-000 - Morrinhos - GO, Brazil.

${ }^{5}$ Universidade Estadual do Norte Fluminense Darcy Ribeiro/ CCTA, Av. Alberto Lamego, 2000, Bairro Horto, CEP $75650-000$ - Campos dos Goytacazes - RJ, Brazil.

${ }^{6}$ Plant-Environment Interactions \& Biodiversity Lab (Plant Stress \&Biodiversity), Linking Landscape, Environment, Agriculture and Food Unit (LEAF), Dept. Recursos Naturais, Ambiente e Território (DRAT), Instituto Superior de Agronomia (ISA), Universidade de Lisboa (ULisboa), Quinta do Marquês, Av. República, 2784-505 Oeiras, Portugal.

${ }^{7}$ Unidade de Geobiociências, Geoengenharias e Geotecnologias (GeoBioTec), Faculdade de Ciências Tecnologia (FCT), Universidade NOVA de Lisboa (UNL), Quinta da Torre, 2829-516 Caparica, Portugal.
\end{abstract}

Corresponding author: Madlles Queiroz Martins (mqm_agroline@hotmail.com).

Abstract: The variation in the climatic conditions throughout the year can influence the foliar nutrient contents in Coffea canephora, impacting the fertilization management. We evaluated the influence of the climatic seasonality on the foliar nutrient contents of $28 C$. canephora genotypes cultivated at 850 meters of altitude, in cold winter. The work was carried out in Morrinhos, State of Goiás, Brazil. A randomized complete block design in a 2 × 28 factorial arrangement was used, with two crop seasons, winter and summer, and $28 \mathrm{C}$. canephora genotypes, with four replications, each replicate composed by five plants, and a spacing of $3.5 \mathrm{~m} \mathrm{x} 1.0 \mathrm{~m}$. The third and fourth pairs of leaves, of productive branches located in the middle third of the plant, were collected in six-year-old crops. The leaves were dried, and the mineral contents were analyzed, they were, then, subjected to multivariate analysis of principal components, dissimilarity and clustering. The results reveal the existence of different nutritional contents among leaves collected in the winter and summer. There is a tendency of higher macro and micronutrient contents in leaves collected in the winter than in the summer. The nutritional diagnosis should consider the group of genotypes and the crop season.

Keywords: Conilon; Environment; Macronutrients; Micronutrients 


\section{Introduction}

More than 150 million bags of coffee were harvested in 2016, worldwide, from which 95 million were produced by Coffea arabica L. and 56 million by C. canephora Pierre ex A. Froehner. Currently, the largest producing countries are Brazil, Vietnam, Colombia, Indonesia, Ethiopia, Honduras and India (ICO, 2018). The coffee income is around USD 173.000 million for the entire coffee chain of value (ICO, 2018), presenting an immense social and economic role in many tropical developing countries, with an estimation that the livelihoods of 25 million smallholder farmers depend on this crop (Van der Vossen, 2016).

Coffea canephora develops well at annual average temperatures of $22{ }^{\circ} \mathrm{C}$ to $26{ }^{\circ} \mathrm{C}$ (Ramalho et al., 2014). Tolerance at temperatures up to $37^{\circ} \mathrm{C}$ is observed through the maintenance or reinforcement of photoprotection and antioxidative mechanisms (Martins et al., 2016; Rodrigues at el., 2016). Although, heat may impact physical attributes, showing decreases in bean mass and yield of coffee (Ramalho et al., 2018a). For C. canephora cv. Conilon, growth is retarded when the minimum average temperature is below $17{ }^{\circ} \mathrm{C}$ and above $31^{\circ} \mathrm{C}$ under field conditions (Partelli et al., 2010; Covre et al., 2016). In general, when the temperature falls below $13{ }^{\circ} \mathrm{C}$, the coffee tree suffers several metabolic and membrane alterations in the composition and structure of the photosynthetic pigment complexes and present negative impact on the photosynthetic machinery functioning (Praxedes et al., 2006; Partelli et al., 2011; Batista-Santos et al., 2011; Scotti-Campos et al., 2014). However, some tolerance has been observed at low positive temperatures that vary according to Coffea species and genotypes, depending on the reinforcement of antioxidative mechanisms and on the dynamics and alteration of the lipid matrix of the chloroplast membranes (Fortunato et al. 2010; Partelli et al., 2011, Ramalho et al., 2014).

Under conditions that promote stomatal closure (eg, water deficit, low temperature), the transpiration flow will be reduced and, hence, the translocation of nutrients from the roots to the leaves will also be reduced (Covre et al., 2018). On the other hand, in plants, the efficiency and priority of certain nutrients absorption by the roots are genetically defined characteristics (Larcher, 2000). In the coffee tree, the mineral nutrients absorption by the roots and their accumulation in the plant vary with location, climate and season of the year, age, organs and tissues (Prezotti and Bragança, 2013). Several studies indicate differences in foliar nutrient content among genotypes of $C$. canephora under the same management conditions (Martins et al., 2015; Gomes et al., 2016). This fact can be explained by the wide intra and interspecific variability among genotypes of $C$. canephora, especially regarding characteristics such as growth, maturation cycle, nutrient accumulation and stress tolerance (Marraccini et al., 2012). This allows the exploration of the diversity for the identification of genetic material more adapted to the several soil and climate conditions existing in the producing regions (Martins et al., 2015).

Considering the lack of studies concerning the foliar nutrient content in genotypes of $C$. canephora cultivated in climate of high altitude, we aimed to evaluate the influence of climatic seasonality on foliar contents of different genotypes of C. canephora cultivated at 850 meters of altitude, with possibility to infer the nutritional diagnosis, under these cultivation conditions.

\section{Material and methods}

The experiment was carried out in Morrinhos, State of Goiás, Brazil, at an altitude of 850 m (Latitude: 49'30" S Longitude: $49^{\circ} 12^{\prime} 01^{\prime \prime} \mathrm{W}$ ). The region is characterized by water deficit from April to October, flat topography, with an average annual temperature of $20^{\circ} \mathrm{C}$ (minimum air temperature varies from 10 to $20^{\circ} \mathrm{C}$ in the winter months, and the average minimum annual temperature is of $18^{\circ} \mathrm{C}$ ), presenting some days with temperature below $8^{\circ} \mathrm{C}$. The experimental crop included 28 genotypes of $C$. canephora Pierre ex A. Froehner (Table 1).

The experiment was established under a randomized block design in a 2 x 28 factorial arrangement, considering two leaf crop seasons (winter: August 9, late summer: March 12) and 28 genotypes (Table 1), with four replications, each composed by five plants of each genotype.

The spacing used in the experimental crop was 3.5 $\mathrm{m} \times 1 \mathrm{~m}$. The cultural treatments corresponding to the fertilization were carried out according to the technical orientations for the coffee crop. Pruning was made to control the number of branches per area, maintaining the standard of 12,000-15,000 stems per hectare. We carried out a manual weeding (tracing the fertilization site), a mechanized weeding and a chemical weeding (per year). No micronutrients, insecticides or fungicides were applied during the study year.

The third and fourth pairs of leaves were collected from productive branches located in the middle third of the plant. After harvest, the leaves were dried in a forced circulation oven for 48 hours at $60-70{ }^{\circ} \mathrm{C}$. Then, leaves were grounded for the nutrient content analysis. For the determination of $\mathrm{N}$ content, the plant material was submitted to sulfur digestion, in which the nitrogen was determined by the Nessler method. The other nutrients $\mathrm{P}$, $\mathrm{K}, \mathrm{Ca}, \mathrm{Mg}, \mathrm{S}, \mathrm{B}, \mathrm{Fe}, \mathrm{Zn}, \mathrm{Mn}$ and $\mathrm{Cu}$ were quantified by ICP-OES, after digestion with concentrated $\mathrm{HNO}_{3}$ and $\mathrm{H}_{2} \mathrm{O}_{2}$ in an open digestion system. ICP conditions: plasma gas $8.0 \mathrm{~L} \mathrm{~min}^{-1}$, auxiliary gas $0.70 \mathrm{~L} \mathrm{~min}^{-1}$ and carrier gas $0.55 \mathrm{~L} \mathrm{~min}^{-1}$, according to Peters' procedures (2005). 
Soil samples were collected at 0-20 and 20-40 layers and analyzed regarding the chemical characteristics by the Embrapa (2009), methodology (Table 2).

Data of the foliar nutrient content of the 27 genotypes evaluated in the study (one of the genotypes died due to the low temperature) were analyzed by the multivariate method through clustering, what generated a dendrogram elaborated from the Euclidean distance matrix and a clustering carried out by the complete linkage clustering (farthest neighbor linkage) (Barroso and Artes, 2003). For the groups formation, a cut-off point was calculated using the constant of 1.25 considering what was suggested by Milligane and Cooper (1985), using the formula: $\left(\mathrm{M}+1.25^{*} \mathrm{sd}\right)$, where: $\mathrm{M}=$ average of the junction points values; $\mathrm{sd}=$ standard error of the junction points values. A multivariate ordering analysis was performed involving principal component analysis.

The data were submitted to analysis of variance using the $\mathrm{F}$ test, with a 5\% level of probability. To compare the average contents of nutrients in coffee leaves, the values obtained for the interaction environment $\mathrm{x}$ groups were analyzed using the Tukey test, adopting a 5\% probability level. All statistical analyzes were performed using the R Core Team program (2016).

\section{Results and discussion}

The cut-off point for the groups separation in the dendogram provided the formation of nine groups of $C$. canephora genotypes based on the evaluated characteristics (Figure 1).

The first, second, third, fourth and eighth groups were composed of a single genotype, 2, 14, 18, 19 and 16 , respectively. The fifth group consisted of genotypes $1,4,6$ and 13 , the sixth by genotypes $25,9,5,8,28$, 20 and 27 , the seventh by genotypes $11,17,3,7,10$, 21 and 24 and the ninth by genotypes 12, 22, 23 and 26 . These nine clusters are considered divergent among each other regarding the foliar nutrient contents from the C. canephora genotypes cultivated at an altitude of 850 meters, where high diversity was identified in terms of foliar nutrient contents. The study of genetic diversity using multivariate techniques is important for planning and defining work strategies in breeding programs (Guedes et al., 2013; Machado et al., 2017). In fact, the use of plant material with genetic variability is determinant for successive breeding programs, providing greater gains in selection (Cruz et al., 2004).

The analysis of variance (Table 3 ) shows that there was no significant interaction between the factors groups of genotypes and crop seasons for the levels of $\mathrm{N}, \mathrm{Mg}$ and Fe (Table 3). Nevertheless, significant differences were found for these nutrients content when the factors genotype group and crop season were observed separately. The existence of differences between groups of genotypes is lined up with the results obtained through the analysis of divergence (Figure 1). In addition, levels of $\mathrm{P}, \mathrm{K}, \mathrm{Ca}$, $\mathrm{S}, \mathrm{B}, \mathrm{Cu}, \mathrm{Mn}$ and $\mathrm{Zn}$ demonstrate significant interaction between the groups of genotypes and crop seasons in the analysis of variance (Table 3 ).

Regarding the two seasons under analysis, the nutrients $\mathrm{N}, \mathrm{Mg}$ and Fe presented higher leaf content in the winter (Table 4). These nutrients have important roles in the photosynthetic machinery, since they determine the level of protein $(\mathrm{N})$, of the enzymes from the CalviBenson cycle, in particular of ribulose 1,5-bisphosphate carboxylase oxygenase ( $\mathrm{RuBisCO})$, the most abundant plant protein, while $\mathrm{Mg}$ is an integral part of the chlorophyll molecule (Taiz et al., 2015). Besides, ca. 80\% of the foliar $\mathrm{Fe}$ occurs in chloroplasts, where it plays an important role in the photosynthesis and biosynthesis of proteins and chlorophyll (Marschner, 1995).

The coffee plant Conilon, when submitted to cultivation at a temperature lower than $17^{\circ} \mathrm{C}$, undergoes leaf dehydration, with stomatal and mesophyll limitations, followed by metabolic alterations, causing damages to the components of the photosynthetic process with differentiated intensities among the genotypes, besides reduced vegetative growth (Partelli et al., 2010; Ramalho et al., 2018b). Thus, it is possible that genotypes of $C$. canephora evaluated in this study suffered stress from temperatures below $17{ }^{\circ} \mathrm{C}$, which occurred during the winter period. This would explain the differences between the contents of these nutrients at this crop season.

A significant interaction between groups of genotypes and seasons of the year (Table 3 ) was observed for the remaining levels of macro $(\mathrm{P}, \mathrm{K}, \mathrm{Ca}, \mathrm{S})$ and micro $(\mathrm{B}, \mathrm{Cu}, \mathrm{Mn}$ and $\mathrm{Zn}$ ) nutrients. For $\mathrm{P}$ foliar contents, significant difference between the seasons of the year was only observed in the third clustering (genotype 18 or NV8), with the lowest value reached in the summer (Table 5), which may be related to the post-flowering phase and filling of grains in which the plants were found. This was also observed in the leaves of Conilon Robusta Tropical in the post-flowering phase, relative to $\mathrm{P}, \mathrm{N}$ and $\mathrm{K}$ (Prezotti and Bragança 2013).

The foliar contents of $\mathrm{K}$ in groups 1, 3 and 4 were also lower in the late summer, period of growth and ripening of fruits. These are the main drain of the plant in this phase, promoting the translocation of minerals and photoassimilates from the leaves to the fruits (Partelli et al. 2014). Also, foliar contents of $\mathrm{S}, \mathrm{Ca}, \mathrm{Cu}, \mathrm{Mn}$ and $\mathrm{Zn}$ present a similar pattern in some groups of coffee genotypes (Table 5), due to fruit ripening, but also due to the higher vegetative growth that some of these genotypes present at that season of the year (Partelli et al., 2014; Covre et al., 2016; Gomes et al., 2016). On the other hand, greater values of minerals such as $\mathrm{Cu}, \mathrm{Zn}, \mathrm{Fe}, \mathrm{Mn}$ in the coolest part of the year, might be related with the strengthening of the antioxidative defense mechanisms, necessary under cold conditions (Ramalho et al., 2013). 
$\mathrm{B}$ was the only foliar nutrient, which content was higher in the summer in 5 of the 9 groups $(4,6,7$ and 9) (Table 5). B is considerably immobile in plants, and its movement into the roots occurs by mass flow until an equilibrium between its concentration in the roots and in the soil is achieved. For that reason, the higher water availability, characteristic of late summer in Brazil, may have resulted in higher B accumulation in the plants (Covre et al., 2018). This micronutrient participates in cell growth, in the biosynthesis of cellular components, in the metabolism of phenols, nucleic acids, carbohydrates and Indole-3-acetic acid (IAA), besides conferring stability and structure to the cell wall (Marschner, 1995).

Regarding the relative contribution of the several nutrients to the discrimination of the formed groups, the analysis of principal components for leaves harvested in the winter showed that the macronutrient $\mathrm{Ca}$ is the one that describes, with more intensity of response, the nutrient contents in group 2 (Figure $2 \mathrm{~A}$ ). For the $7^{\text {th }}$ genotype group, $\mathrm{Mg}$ was the macronutrient that best described the behavior of this group.

The nutrients $\mathrm{N}, \mathrm{P}$ and $\mathrm{S}$ describe group 8 more strongly, where $\mathrm{P}$ represents a greater influence on the responses of the nutrient contents to group 8 when compared to nutrients $\mathrm{N}$ and $\mathrm{S}$. The nutrient $\mathrm{K}$ discriminates, in a greater degree, the response of the groups of genotypes 9 and 4 . For the groups of genotypes $1,5,6$ and 3, there was no macronutrient in this study that explains, with great intensity, the response of these groups regarding the nutrient contents (Figure 2A). K and $\mathrm{Mg}$ were the most important nutrients to discriminate the groups of genotypes of $C$. canephora according to the nutrient contents in leaves harvested in the winter.

In a similar analysis for the micronutrients (Figure 2B), Fe explains with great intensity the group of genotypes 1 and 2. In comparison with $\mathrm{Fe}$, the micronutrient $\mathrm{Zn}$ describes group 2 in a greater degree. The response according to the nutrient content of groups of genotypes 7 and 8 are strongly explained by the $\mathrm{Cu}$ micronutrient, and this nutrient explains in a greater degree the behavior for the nutrient content of group 7 when compared to group 8. Regarding groups 9, 5, 4, 3 and 6, no micronutrients were found to describe the response of these groups to the nutrient content, with great intensity, suggesting that the contribution of micronutrients to these groups of genotypes occurred more evenly.

Regarding the macronutrient foliar content in the summer (Figure 3A), N explains the nutrient content response of group 5. Magnesium describes, in a greater degree, group 7, as in the winter. Calcium describes groups 2 and 3 with different intensities (Figure 3A) and is similar to that observed in the winter for group 2. Because it is a nutrient with low mobility in the plant, it is expected little variation between leaves crop seasons within the same genotype groups. Finally, S explains with certain degree of discrimination, groups of genotypes 3 and 4 , and $\mathrm{P}$ explains with great intensity, the behavior for groups 8 and 6 , with more emphasis on the latter. The response to the ninth genotype group was largely explained by K. Only the first genotype group does not seem to be described by any of the evaluated macronutrients.

Regarding the foliar micronutrient content in the summer (Figure 3B), $\mathrm{Zn}, \mathrm{B}, \mathrm{Mn}$ and $\mathrm{Cu}$ describe in a high degree the response of group 3. Manganese explains, although with small intensity, the response of group 4 for the micronutrient contents in the leaves in the summer. Groups 2 and 7 are described by Fe, while groups of genotypes 1, 5, 6, 8 and 9 were not discriminated with great intensity by any of the micronutrients (Figure 3B).

In general, there is a pattern of nutrient content differentiated when the interaction between the variables macro and micronutrients and groups of genotypes is observed in a comparison between the two sampling seasons at altitude (Figures 2 and 3 ). The response pattern that more strongly discriminates the results for analysis of principal components of this study were presented by macronutrients in leaves harvested in the summer (Figure $3 \mathrm{~A})$. This response can be explained by the favorable climatic conditions in which the plants grew when the leaves were collected (late summer).

Finally, the results of the study indicate that groups of genotypes of $C$. canephora cultivated at high altitudes suffered significant changes in the nutrient content of leaves collected in the winter and late summer. This difference indicates the presence of promoting or inhibiting factors (edaphoclimatic and other factors) occurring during the year in these climatic conditions that along with the genetic variability of the coffee trees, caused variations in nutrient contents in the leaves collected in winter and summer, at high altitude. Thus, the nutritional management of these plants should consider season and genotypes. The results observed in this study can be considered similar to that identified by Giles et al. (2018), in which, by studying promising genetic coffee conilon materials, they concluded that among the evaluated genotypes there is genetic diversity indicating potential for actions aimed at the improvement of coffee plants. 
Table 1. List of the 28 genotypes of C. canephora used in the experiment, in the Institute Federal Goiano, in Morrinhos - GO.

\begin{tabular}{cccc}
\hline A & AC & A & AC \\
\hline $1 \mathrm{~V}$ & 1 & NV2 & 14 \\
$2 \mathrm{~V}$ & 2 & 14 from EMCAPA 8121 & 15 \\
$3 \mathrm{~V}$ & 3 & Clone 18 & 16 \\
$4 \mathrm{~V}$ & 4 & NV1 & 17 \\
$5 \mathrm{~V}$ & 5 & NV8 & 18 \\
$6 \mathrm{~V}$ & 6 & P1 & 19 \\
$7 \mathrm{~V}$ & 7 & from EMCAPA 8121 & 20 \\
$8 \mathrm{~V}$ & 8 & P2 & 21 \\
$9 \mathrm{~V}$ & 9 & 4 from Bahia & 22 \\
$10 \mathrm{~V}$ & 10 & NV3 & 23 \\
$11 \mathrm{~V}$ & 11 & Verdim TA & 24 \\
$12 \mathrm{~V}$ & 12 & A1 & 25 \\
$13 \mathrm{~V}$ & 13 & Robustão Seeds & 26,27 and 28 \\
\hline
\end{tabular}

*(A): Accessions; (AC): Accessions code, corresponding to 28 genotypes of C. Canephora analyzed in the experiment. V1 to V2 - genotypes that compose the Vitória cultivar. A1 - composes the Tributun cultivar. 3 and 14 from Emcapa - compose the Emcapa 8121cultivar.

Table 2. Chemical and granulometric characterization of soils collected in the experimental area of the study, Morrinhos $-\mathrm{GO}$

\begin{tabular}{|c|c|c|c|c|c|c|c|c|c|c|c|c|c|c|}
\hline Samples & $\mathrm{pH}$ & $\mathrm{P}$ & $\mathrm{K}$ & $\mathrm{Na}$ & $\mathrm{Ca}$ & $\mathrm{Mg}$ & $\mathrm{Al}$ & $\mathrm{H}+\mathrm{Al}$ & $\mathrm{SB}$ & $\mathrm{t}$ & $\mathrm{T}$ & V & $\mathrm{m}$ & $\mathrm{OM}$ \\
\hline & $\mathrm{H}_{2} \mathrm{O}$ & \multicolumn{3}{|c|}{$\mathrm{mg} \mathrm{dm}^{-3}$} & \multicolumn{7}{|c|}{ cmolc dm ${ }^{-3}$} & $\%$ & $\%$ & $\mathrm{~g} \mathrm{Kg}^{-1}$ \\
\hline $0-20$ & 5.45 & 1.43 & 92 & 5 & 2.44 & 0.39 & 0.05 & 5.28 & 5.09 & 3.14 & 8.37 & 36.92 & 1.59 & 32.23 \\
\hline $20-40$ & 5.41 & 0.61 & 51 & 3 & 1.74 & 0.34 & 0.05 & 4.78 & 2.22 & 2.27 & 7.00 & 31.69 & 2.20 & 30.23 \\
\hline \multirow{2}{*}{\multicolumn{2}{|c|}{ Samples }} & \multicolumn{3}{|c|}{ Total sand } & & Silt & \multicolumn{3}{|c|}{ Clay } & \multicolumn{4}{|c|}{ Classification } & \\
\hline & & \multicolumn{3}{|c|}{$\%$} & & $\%$ & \multicolumn{3}{|c|}{$\%$} & & & & & \\
\hline \multicolumn{2}{|l|}{$0-20$} & \multicolumn{3}{|c|}{34} & & 6 & \multicolumn{3}{|c|}{60} & \multicolumn{4}{|c|}{ Argillaceous texture } & \\
\hline \multicolumn{2}{|c|}{$20-40$} & \multicolumn{3}{|c|}{33} & & 6 & \multicolumn{3}{|c|}{61} & \multicolumn{4}{|c|}{ Very argillaceous texture } & \\
\hline
\end{tabular}

*Available phosphorus (P), exchangeable potassium $(\mathrm{K})$, sodium $(\mathrm{Na})$, calcium $\left(\mathrm{Ca}^{2+}\right)$ and magnesium $\left(\mathrm{Mg}^{2+}\right)$, exchangeable aluminum $\left(\mathrm{Al}^{3+}\right)$, Sum of exchangeable bases (SB), cation effective capacity at $\mathrm{pH} 7(\mathrm{t})$ and exchangeable capacity $(\mathrm{T})$, base saturation $(\mathrm{V})$, organic matter (OM), and aluminum saturation index (m). 


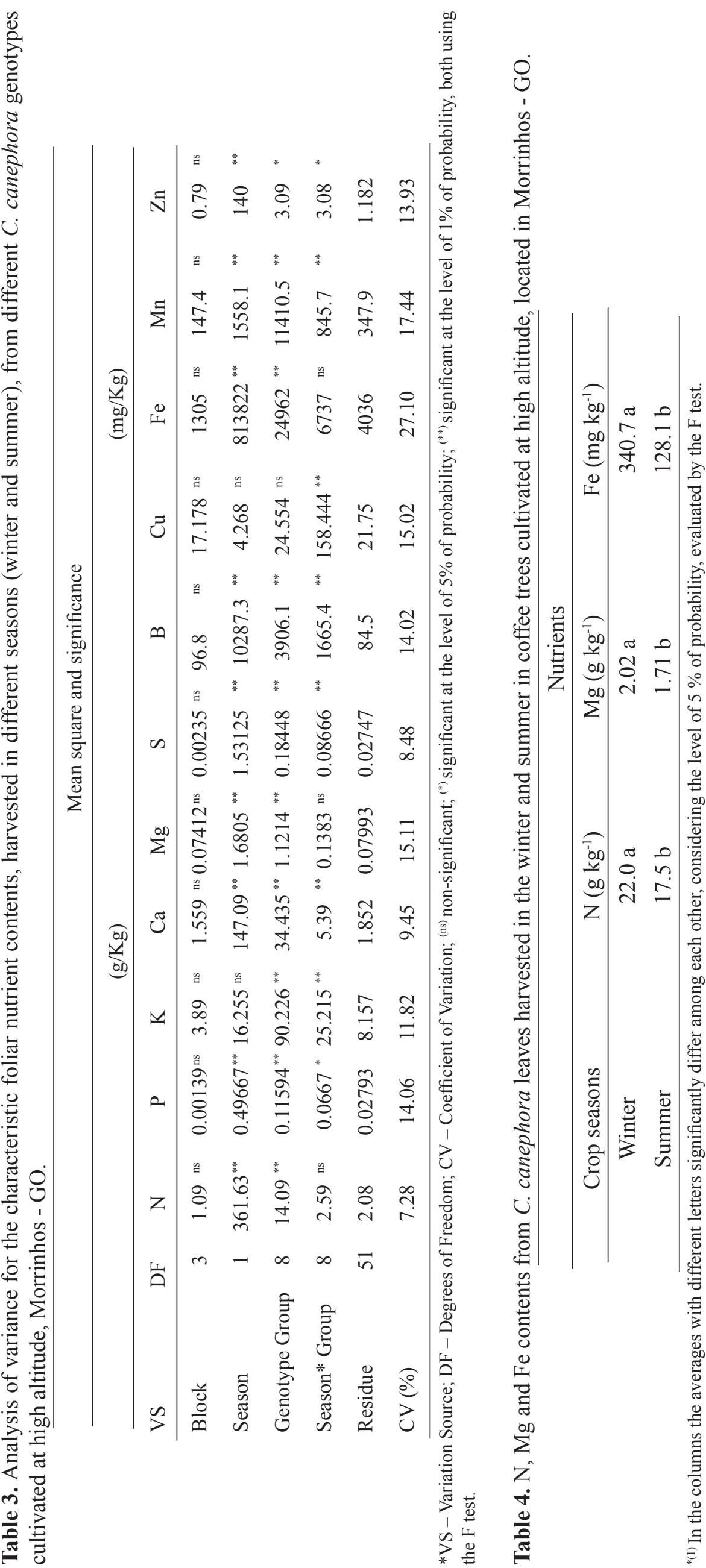

FPBJ - Scientific Journal 


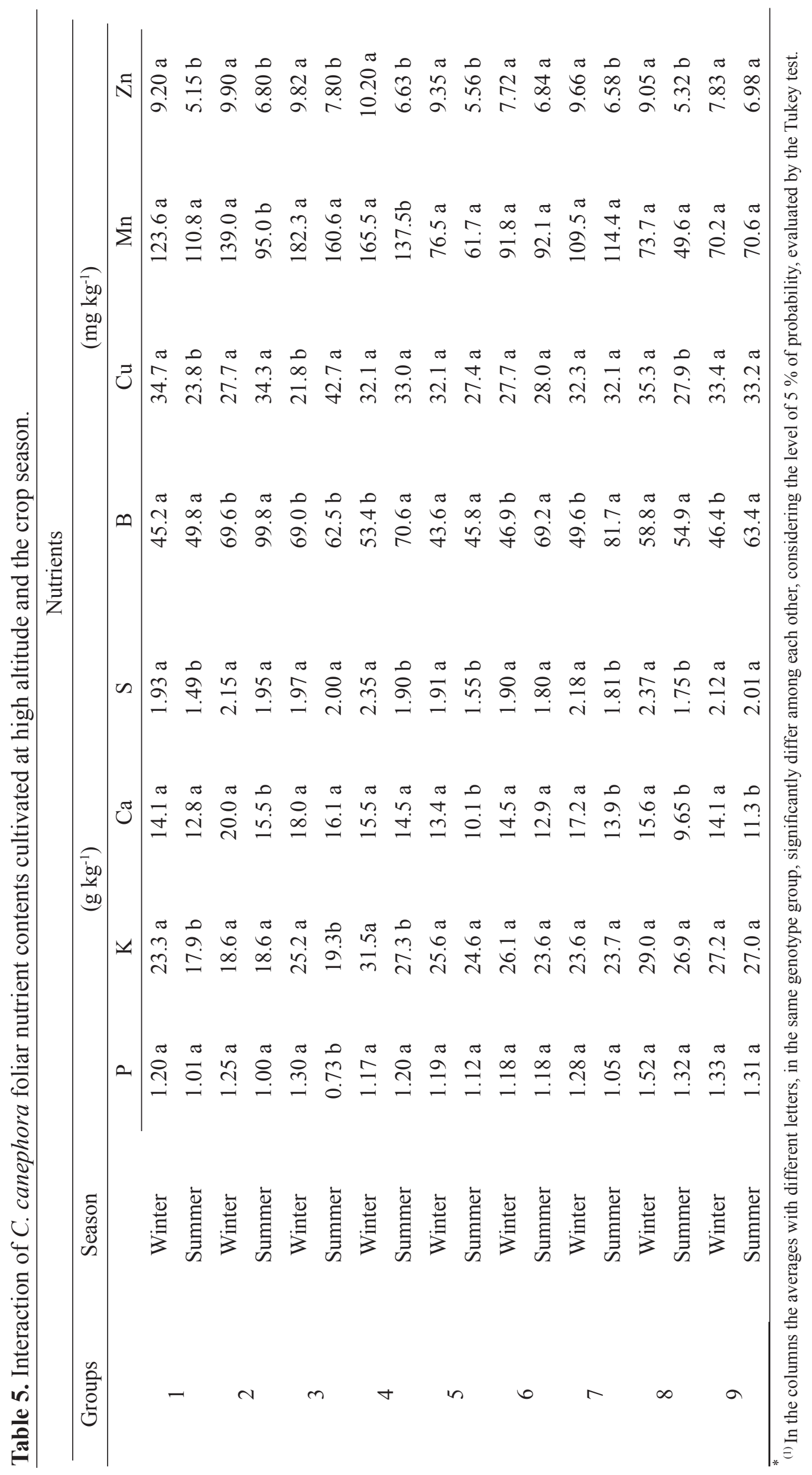




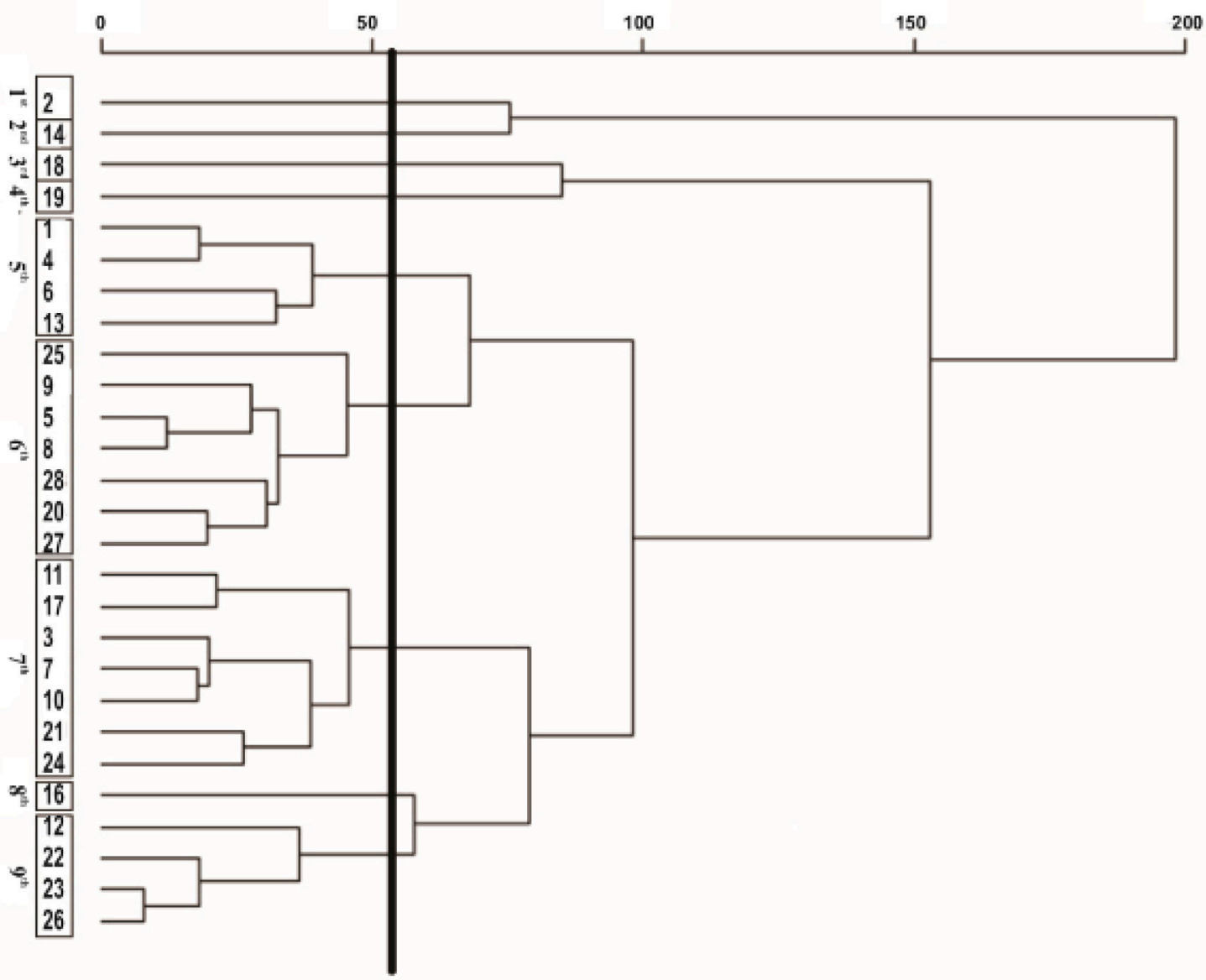

Figure 1. Dendrograms created with the complete linkage, from the genetic dissimilarity matrix using the Euclidean distance, the variable average foliar nutrient content in leaves of 27 genotypes of $C$. canephora, collected in two seasons (winter and summer), cultivated in the south of the cerrado region of Goiás. Morrinhos - GO.
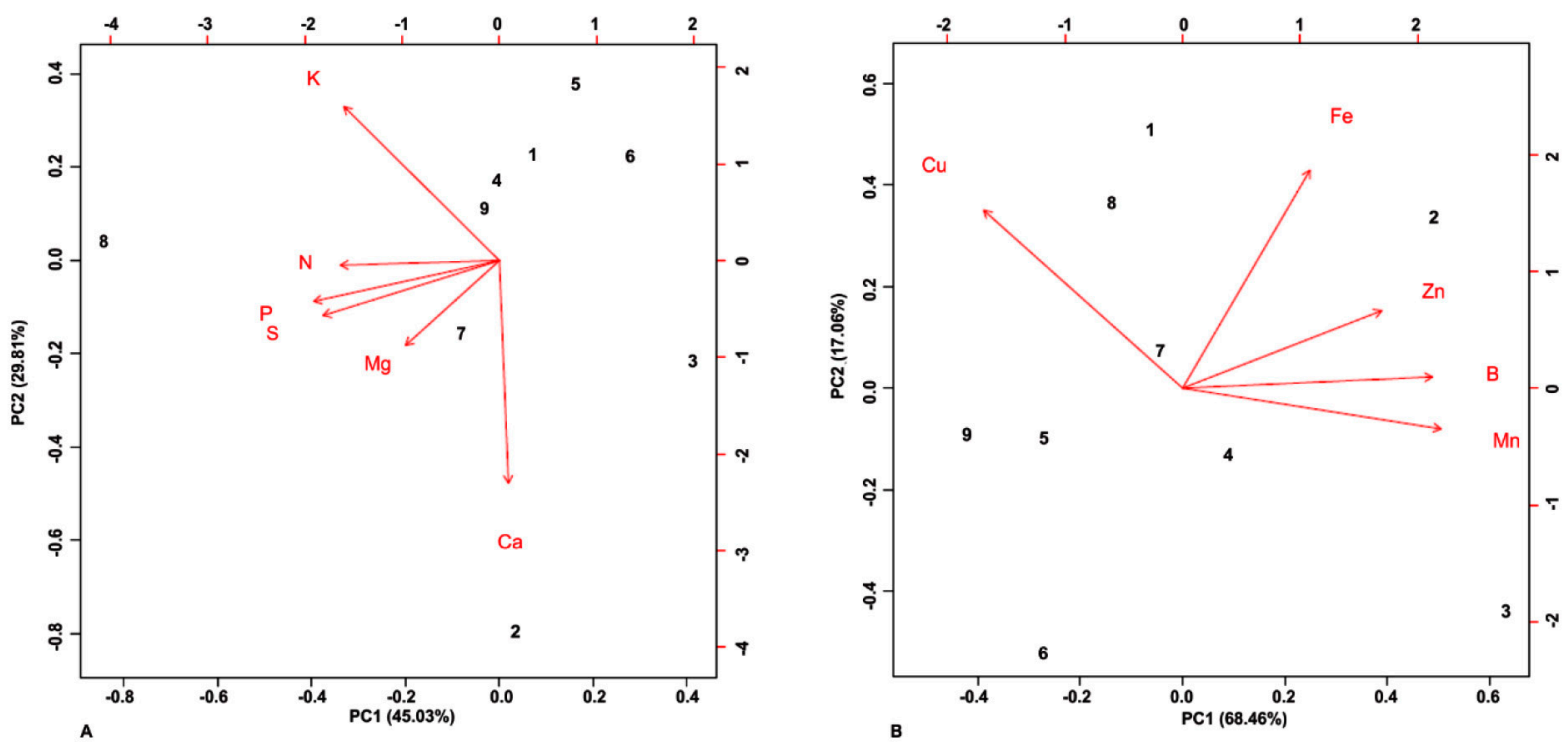

Figure 2. Graph of scores of the PC1 x PC2 referring to the macronutrients (A) and micronutrients content (B) in leaves of coffee trees collected in the winter, representative of nine groups of genotypes of $C$. canephora, cultivated at high altitude in Morrinhos - GO. 

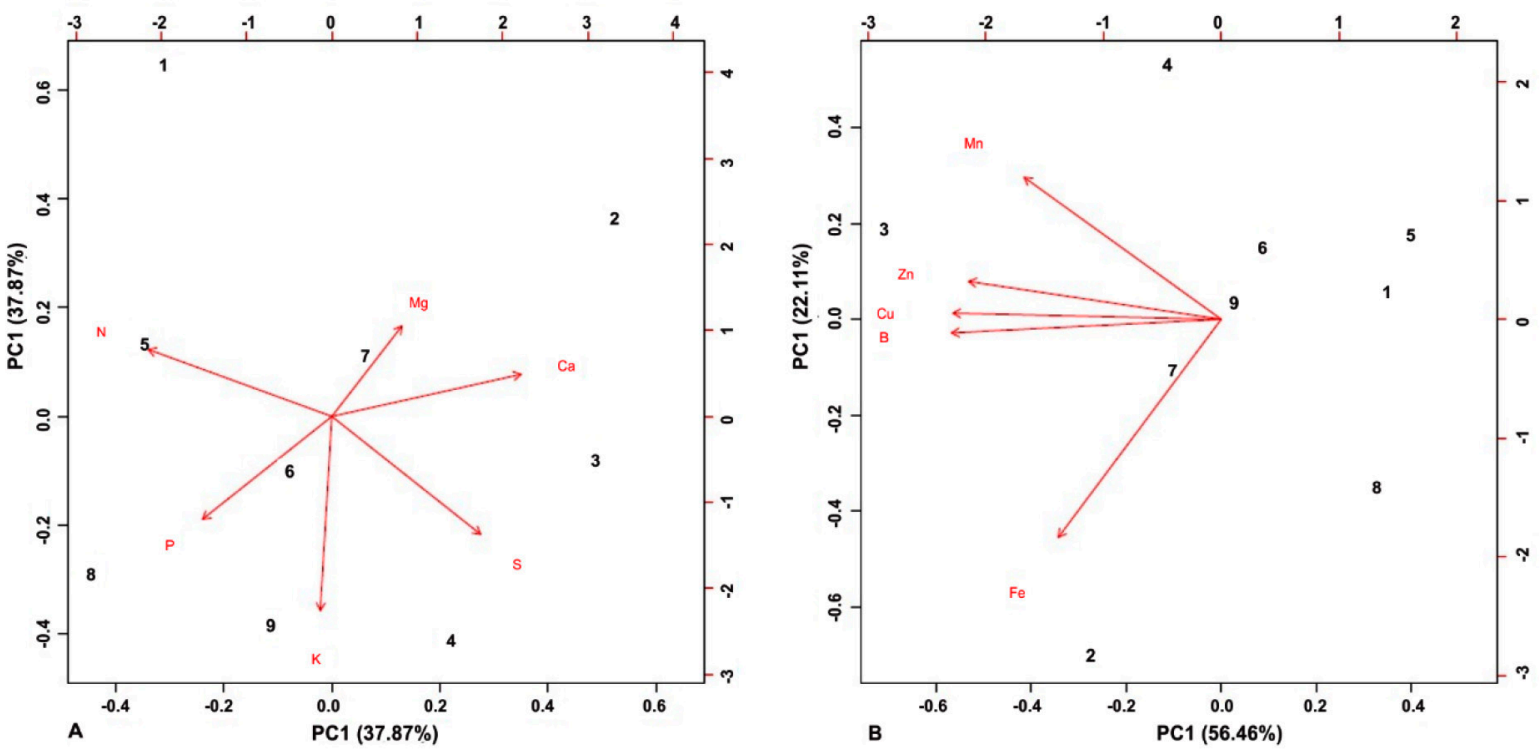

Figure 3. Graph of scores of the PC1 x PC2 referring to the macronutrients (A) and micronutrients content (B) in leaves of coffee trees collected in the summer, representative of nine groups of genotypes of $C$. canephora, cultivated at high altitude in Morrinhos - GO.

\section{Conclusions}

In conclusion, we observed difference in foliar macro and micronutrient contents between the two seasons (winter and summer) of the studied year, somewhat differently among the 28 studied genotypes of $C$. canephora cultivated at an altitude of $850 \mathrm{~m}$. The nutrients $\mathrm{N}, \mathrm{Mg}$ and $\mathrm{Fe}$ were found with higher content in the leaves harvested in the winter in comparison to the leaves harvested in the summer. Significant interactions are present between nutrient content of the leaves harvested in the winter and summer, and the analysis of principal components highlighted the nutrients that discriminated, to a greater or lower degree, the content of nutrients present in the leaves of the different coffee groups collected at $850 \mathrm{~m}$ altitude, in the winter and summer. The nutritional diagnosis should consider the group of genotypes and the crop season.

\section{Acknowledgements}

The authors thank the Federal University of Espírito Santo for the support to this investigation, the Goiano Federal Institute of Morrinhos, GO, for the availability of experimental resources, the Capixaba Institute of Research, Technical Assistance and Rural Extension, for providing seedlings of part of the accessions of genotypes of $C$. canephora analyzed in the study, the Foundation for Research and Innovation Support of Espírito Santo (FAPES), for the financial support, and the National Council of Scientific and Technological Development (CNPq) for financing the crop implementation and the research productivity fellowship.

\section{References}

BARROSO, L.P.; ARTES, R. 2003. Análise multivariada. UFLA: Lavras, 151p.

BATISTA-SANTOS, P.; LIDON, F.C.; FORTUNATO, A.; LEITÃO, A.E.; LOPES, E.; PARTELLI, F.L.; RIBEIRO, A.I.; RAMALHO, J.C. 2011. The impact of cold on photosynthesis in genotypes of Coffea spp. photosystem sensitivity, photoprotective mechanisms and gene expression. Journal of Plant Physiology, 168(8):792806.

COVRE, A.M.; PARTELLI, F.L.; BONOMO, R.; BRAUN, H.; RONCHI, C.P. 2016. Vegetative growth of Conilon coffee plants under two water conditions in the Atlantic region of Bahia State, Brazil. Acta Scientiarum. Agronomy, 38(4):535-545. 
COVRE, A.M.; PARTELLI, F.L.; BONOMO, R.; GONTIJO, I. 2018. Micronutrients in the fruits and leaves of irrigated and non-irrigated coffee plants. Journal of Plant Nutrition, 41(9):1119-1129.

CRUZ, C.D.; REGAZZI, A.J.; CARNEIRO, P.C.S. 2004. Modelos biométricos aplicados ao melhoramento genético. 3. ed. UFV: Viçosa, v.1. 480p.

EMBRAPA - Empresa Brasileira de Pesquisa Agropecuária. Manual de análise química dos solos, plantas e fertilizantes. 2009. 2. ed. Brasília. 627p.

FORTUNATO, A.; LIDON, F.C.; BATISTA-SANTOS, P.; LEITÃO, A.E.; PAIS, I.P.; RIBEIRO, A.I.; RAMALHO, J.C. 2010. Biochemical and molecular characterization of the antioxidative system of Coffea sp. under cold conditions in genotypes with contrasting tolerance. Journal of Plant Physiology, 167, 333-342.

GILES, J.A.D.; PARTELLI, F.L.; FERREIRA, A.; RODRIGUES, J.P.; OLIOSI, G.; SILVA, F.H.L. 2018. Genetic diversity of promising 'conilon' coffee clones based on morpho-agronomic variables. Anais da Academia Brasileira de Ciências, 90(2):2437-2446.

GOMES, W.R.; RODRIGUES, W.P.; VIEIRA, H.D.; OLIVEIRA, M.G.; DIAS, J.R.M.; PARTELLI, F.L. 2016. Genetic diversity of standard leaf nutrients in Coffea canephora genotypes during phenological phases. Genetics and Molecular Research, 15(4):1-13.

GUEDES, J.M.; VILELA, D.J.M.; REZENDE, J.C.; SILVA, F.L.; BOTELHO, C.E.; CARVALHO, S.P. 2013. Divergência genética entre cafeeiros do germoplasma Maragogipe. Bragantia, 72(2):127-132.

ICO - International Coffee Organization. Trade Statistics. $<$ http://www.ico.org/trade_statistics.asp $>$. Accessed: 10 July 2018.

LARCHER, W. 2000. Ecofisiologia vegetal. Rima Artes e Textos: São Paulo, 531p.

MACHADO, C.M.S.; PIMENTEL, N.S.; GOLYNSK, A.; FERREIRA, A.; VIEIRA, H.D.; PARTELLI, F.L. 2017. Genetic diversity among 16 genotypes of Coffea arabica in the Brazilian cerrado. Genetics and Molecular Research, 16(3):1-13.

MARRACCINI, P.; VINECKY, F.; ALVES, G.S.C.; RAMOS, H.J.O.; ELBELT, S.; VIEIRA, N.G.; CARNEIRO, F.A.; SUJII, P.S.; ALEKCEVETCH, J.C.; SILVA, V.A.; DAMATTA, F.M.; FERRÃO, M.A.G.; LEROY, T.; POT, D.; VIEIRA, L.G.E.; SILVA, F.R.; ANDRADE, A.C. 2012. Differentially expressed genes and protein sup on drought acclimation in tolerant and sensitive genotypes of Coffea canephora. Journal of Experimental Botany, 63:4191-4212.

MARSCHNER, H. 1995. Mineral nutrition of higher plants. 2. ed. Academic Press: London, 889p.

MARTINS, L.D.; RODRIGUES, W.N.; MACHADO, L.; BRINATE, S.V.B.; COLODETTI, T.V.; AMARAL, J.F.; TOMAZ, M.A. 2015. Evidence of genetic tolerance to low availability of phosphorus in the soil among genotypes of Coffea canephora. Genetics and Molecular Research, 14:10576-10587.

MARTINS, M.Q.; RODRIGUES, W.P.; FORTUNATO, A.S.; LEITÃO, A.E.; RODRIGUES, A.P.; PAIS, I.P.; MARTINS, L.D.; SILVA, M.J.; REBOREDO, F.H.; PARTELLI, F.L.; CAMPOSTRINI, E.; TOMAZ, M.A.; SCOTTI-CAMPOS, P.; RIBEIRO-BARROS, A.I.; LIDON, F.J.; DAMATTA, F.M.; RAMALHO, J.C. 2016. Protective response mechanisms to heat stress in interaction with high $\left[\mathrm{CO}_{2}\right]$ conditions in Coffea spp. Frontiers in Plant Science, 7:947.

MILLIGAN, G.W.; COOPER, M.C. 1985. An examination of procedures for determining the number of cluster in data set. Psychometrika, 50:159-179. 
PARTELLI, F.L.; BATISTA-SANTOS, P.; SCOTTI-CAMPOS, P., PAIS, I.P.; QUARTIN, V.L., VIEIRA, H.D.; RAMALHO, J.C. 2011. Characterization of the main lipid components of chloroplast membranes and cold induced changes in Coffea spp. Environmental and Experimental Botany, 74(1):194-204.

PARTELLI, F.L.; ESPINDULA, M.C.; MARRÉ, W.B.; VIEIRA, H.D. 2014. Dry matter and macronutrient accumulation in fruits of Conilon coffee with different ripening cycles. Revista Brasileira de Ciência do Solo, 38(1):214-222.

PARTELLI, F.L.; VIEIRA, H.D.; SILVA, M.G.; RAMALHO, J.C. 2010. Seasonal vegetative growth of different age branches of Conilon coffee tree. Semina: Revista Brasileira de Ciências Agrárias, 31(3):619-626.

PETERS, J.B. 2005. Wisconsin Procedures for Soil Testing, Plant Analysis and Feed \& Forage Analysis: Plant Analysis. Department of Soil Science, College of Agriculture and Life Sciences, University of Wisconsin-Extension, Madison, WI. <http://uwlab.soils.wisc.edu/files/procedures/plant_icp.pdf>. Accessed: 20 February 2014.

PRAXEDES, S.C.; DAMATTA, F.M.; LOUREIRO, M.E.; FERRÃO, M.A.G.; CORDEIRO, A.T. 2006. Effects of long-term soil drought on photosynthesis and carbohydrate metabolism in mature robusta coffee (Coffea canephora Pierre var. kouillou) leaves. Environmental and Experimental Botany, 56(3):263-273.

PREZOTTI, L.C.; BRAGANÇA, S.M. 2013. Concentração de massa seca, N, P e K em diferentes materiais genéticos de café conilon. Coffee Science, 8(3):284-294.

R CORE TEAM. (2016). R: A language and environment for statistical computing. R Foundation for Statistical Computing, Vienna, Austria. URL https://www.R-project.org/.

RAMALHO, J.C.; PAIS, I.P.; LEITÃO, A.E.; GUERRA, M.; REBOREDO, F.H.; MÁGUAS, C.M.; CARVALHO, M.L.; SCOTTI-CAMPOS, P.; RIBEIRO-BARROS, A.I.; LIDON, F.J.C.; DAMATTA, F.M.; 2018a. Can Elevated Air $\left[\mathrm{CO}_{2}\right]$ Conditions Mitigate the Predicted Warming Impact on the Quality of Coffee Bean? Frontiers in Plant Science, 9:1-14.

RAMALHO, J.C.; RODRIGUES, A.P.; LIDON, F.C.; MARQUES, L.M.C.; LEITÃO, A.E.; FORTUNATO, A.S. PAIS, I.P.; SILVA, M.J.; SCOTTI-CAMPOS, P.; LOPES, A.; REBOREDO, F.H.; RIBEIRO-BARROS, A.I. 2018b. Stress cross-response of the antioxidative system promoted by superimposed drought and cold conditions in Coffea spp. Plos One, 13(6):1-30.

RAMALHO, J.C.; FORTUNATO, A.S.; GOULÃO, L.F.; LIDON, F.C. 2013. Cold-induced changes in mineral content in leaves of Coffea spp. Identification of descriptors for tolerance assessment. Biologia Plantarum, 57(3):495-506.

RAMALHO, J.C.; DAMATTA, F.M.; RODRIGUES, A.P.; SCOTTI-CAMPOS, P.; PAIS, I.; BATISTA-SANTOS, P.; PARTELLI, F.L.; RIBEIRO, A.; LIDON, F.C.; LEITÃO, A.E. 2014. Cold impact and acclimation response of Coffea spp. plants. Theoretical and Experimental Plant Physiology, 26:5-18.

RODRIGUES, W.P.; MARTINS, M.Q.; FORTUNATO, A.S.; RODRIGUES, A.P.; SEMEDO, J.N.; SIMÕES-COSTA, M.C.; PAIS, I.P.; LEITÃO, A.E.; COLWELL, F.; GOULAO, L.; MÁGUAS, C.; MAIA, R.; PARTELLI, F.L.; CAMPOSTRINI, E.; SCOTTI-CAMPOS, P.; RIBEIRO-BARROS, A.I.; LIDON, F.C.; DAMATTA, F.M.; RAMALHO, J.C. 2016. Long-term elevated air $\left[\mathrm{CO}_{2}\right]$ strengthens photosynthetic functioning and mitigates the impact of supra-optimal temperatures in tropical Coffea arabica and C. canephora species. Global Change Biology, 22:415-431.

SCOTTI-CAMPOS, P.; PAIS, I.P.; PARTELLI, F.L.; BATISTA-SANTOS, P.; RAMALHO, J. C. 2014. Phospholipids profile in chloroplasts of Coffea spp. genotypes differing in cold acclimation ability. Journal of Plant Physiology, 171(3):243-249. 
TAIZ, L.; ZEIGER, E.; MØLlER, I.M.; MURPHY, A. 2015. Plant Physiology and Development. 6. ed. Sinauer Associates, Sunderland, MA.

VAN DER VOSSEN, H. 2016. Narrowing the yield gap of smallholder coffee production as sustainable strategy to meet rising demand for quality coffees. The 26th International Conference on Coffee Science. Kunming - China, 2 p. 